\title{
Primary Assessment of the Degree of Torrefaction of Biomass Agricultural Crops
}

\author{
Serhii Yermakov \\ Educational and Scientific \\ Laboratory "DAK GPS", \\ State Agrarian and Engineering \\ University in Podilia, \\ Kamianets-Podilskyi,Ukraine \\ dakgps@pdatu.edu.ua \\ Vadym Hulevskyi \\ Faculty of Energy and Computer \\ Technology \\ Dmitry Motornyi Tavria State \\ Agrotechnological University, \\ Melitopol, Ukraine
}

\author{
Taras Hutsol \\ Institute of Energy, \\ State Agrarian and Engineering \\ University in Podilia, \\ Kamianets-Podilskyi,Ukraine \\ pro-gp@pdatu.edu.ua
}

\author{
Viktoriia Pylypenko \\ Agrobiological Faculty, \\ National University of Life and \\ Environmental Science, \\ Kyiv, Ukraine
}

\author{
Szymon Glowacki \\ Institute of Mechanical Engineering \\ Warsaw University of Life Sciences - \\ SGGW \\ Warsaw, Poland \\ glowackisz@gmail.com
}

\begin{abstract}
Biomass energy is an important component in the overall structure of renewable energy and has the greatest potential for increasing volumes. However, the peculiarities of the properties of agro-industrial residues are a significant disadvantage of their widespread use. The process of torrefaction allows to bring the characteristics of biofuel as close as possible to thermal coal. Different degree of heat treatment of biomass leads to a product with different heating value. Therefore, it is important to know the optimal mode of torrefaction, which will provide the best energy parameters of biofuels.
\end{abstract}

Researches of torrefaction were carried out on the basis of educational and scientific laboratory "DAK GPS" of the State Agrarian and Engineering University in Podilia. The kinetics of the relative mass of different types of biomass at different processing temperatures was considered. The dependence of the degree of torrefaction on the heat treatment temperature is revealed. As shown by studies for most biomaterials of plant origin, we can distinguish the beginning of intensive transformation and its end, after which there is a sharp slowdown in weight loss, and, accordingly, and the energy density of the samples.

Keywords - biomass, torrefaction, thermal treatment, energy intensity biofuels, thermal decomposition, thermogravimetric investigation.

\section{INTRODUCTION}

The growth rate of the bioenergy sector in the world is constantly growing, which requires the expansion of opportunities and improvement of technologies in existing areas of renewable energy. From this point of view, one of the most promising renewable energy sources is biomass.

The main sources of biomass are agricultural waste and residues (straw, stalks and rods of corn, stalks and husks of sunflower), as well as energy crops (willow, poplar, miscanthus), which are grown specifically for this purpose. Increasing the volume of such raw materials is an agronomic issue, and in the field of improving the energy properties of biomass there are already significant successes, but scientific research is still underway. The main obstacles to the use of plant biomass as a solid fuel are then some of its physical characteristics: low energy density, heterogeneity, particle size, etc. The peculiar chemical-physical properties, which appear as highly variable shape, size, moisture content, density, chemical composition (different proportion and nature of the hemicellulose, cellulose and lignin) and high concentrations of minor species, such as chlorine, alkali metals, nitrogen and sulphur, strongly modify the reactivity of both the starting material and the intermediate products of the decomposition and gasification processes.

The production of standardised upgraded biomass with low cost technology will definitively constitute a 
prerequisite to produce biofuels rather than the use of raw biomass.

One of the ways to obtain a product with such properties from biomass is its torrefaction - the process of "soft" pyrolysis of biomass, heating without access of air, which takes place at temperatures of $200-320{ }^{\circ} \mathrm{C}$ and atmospheric pressure for 15-30 minutes.

The torrefaction process is aimed at improving the properties of biomass as a fuel. It consists of a slow heating of biomass in an inert atmosphere to a maximum temperature of $300{ }^{\circ} \mathrm{C}$. The treatment results in a solid uniform product with lower moisture content and higher energy content compared to those in the initial biomass. The solid product retains approximately $70 \%$ of the initial weight and $80-90 \%$ of the original energy content [1-3].

The following property changes can be achieved by torrefaction:

- Increase of the heating value per weight unit.

- Improved hydrophobic nature. Torrefied biomass is hydrophobic and contains a very low moisture content. It does not egain humidity during storage and therefore it can be stored outside.

\section{- Improved grinding properties [4]}

- Increased uniformity and durability. The composition of torrefied biomass is uniform. The production process is controllable. This makes it a suitable solid fuel for combustion and gasification applications.

One of the big advantages of the torrefaction technology is that it converts biomass feedstocks, which generally do not have uniform qualities, into more uniform materials with predictable and controllable fuel properties $[5,6]$.

Torrefied products can substitute charcoal in various applications.

The thermogravimetric method of analysis is widely used to study the torrefaction process. This method allows not only to obtain quantitative characteristics of the process of term decomposition, but also to describe this process with sufficient accuracy in the form of kinetic equations [7]. Although such studies are the most accurate, they are not so common in the literature $[8,9]$, which is due to the high complexity of the experiments and the need to have the appropriate equipment.

For production conditions it is important first of all qualitative characteristics of the final product which depend on modes of thermal processing of biomass. This is due to the fact that in the process of torrefaction is not only the removal of moisture from the raw material (drying), but also the partial thermal destruction of the organic component of biomass. It is accompanied by changes that can be detected and evaluated not only by complex laboratory analysis, but also by simple measurements, weighing or even organoleptic evaluation of samples. According to the parameters that characterize the level of thermal transformations of biomass can be a change in color, weight loss, change in shape and size, the acquisition of new properties (fragility, hardness, etc.).

\section{MATERIALS AND METHODS}

It continues the work on the scientific topic "Agrobiomass of Ukraine as an energy potential of Central and Eastern Europe" (registration number 0119U103056) at the State Agrarian and Engineering University in Podilia, the joint Ukrainian-Polish educational and scientific laboratory "DAK GPS"[10-17]. The main activity of the laboratory is to improve the energy performance of biomass by thermal treatment (torrefaction), which results in torrefied products. Investigations of the primary signs of the state of heattreated raw materials were carried out on a plant for torrefaction of tape-type biomass with passive interaction with the material. This method minimizes the physical and mechanical effects on the raw material, and the flow of the process allows to get the most homogeneously processed product.

Selected biomass samples using laboratory scales were divided into equal-weight portions of 50-100 g, which were alternately subjected to heat treatment at seven temperature regimes: $180,200,220,240,260,280$ and $300{ }^{\circ} \mathrm{C}$. The temperature range $180-300$ fully meets the conditions of the torrefaction process.

To bring the data to a more traditional form, it is necessary to build thermogravimetric curves in addition to the weight loss curves. To construct the curves, the loss in mass of the substance during heating to high temperatures is determined. The curve of the dependence of mass loss on temperature is plotted in the coordinates of the abscissa - temperature, ordinate - mass loss in grams or percent (Fig. 1). Such a curve called simple or integral shows all the mass loss from the beginning to the end of heating.

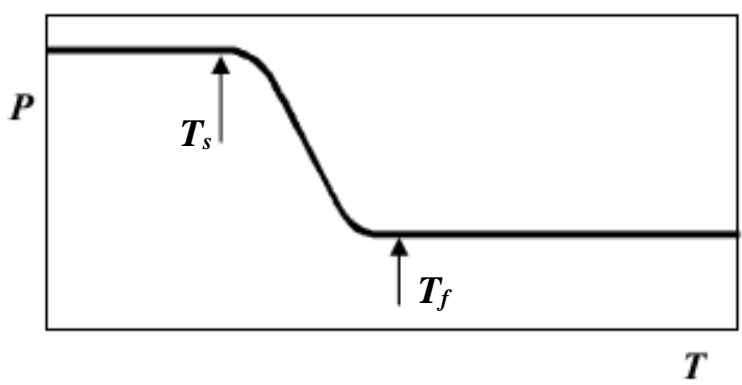

Fig. 1. Characteristics of the thermogravimetric curve in the case of a one-stage reaction

In Fig. 1 shows the characteristics of the curve of mass reduction in the case of a single-stage reaction. For any one-stage non-isometric reaction, you can choose two characteristic points on the thermogravimetric curve: a) the initial decomposition temperature $T_{s}$, ie the temperature at which the total change in mass reaches the sensitivity of thermobalances; b) the final temperature $T_{f}$, ie the temperature at which the total change in mass reaches a maximum value corresponding to the completion of the reaction. The difference $T_{f}-T_{s}$ is called the reaction 
interval. These threshold values will determine the start and end modes of torrefaction.

\section{RESULTS AND DISCUSSION}

Any heat treatment of organic matter is primarily associated with the removal of moisture and thermally unstable elements, as well as with the transformations caused by the action of temperature. The basic classification of the bonds between moisture and material is usually a scheme where all bonds are divided into chemical, physicochemical (adsorption and osmotic) and physico-mechanical (wetting fluid and contained in capillaries). Chemically bound moisture has the highest binding energy to the material and is in a certain quantitative ratio with the dry matter. This moisture can be removed from the wood at temperatures above $180^{\circ} \mathrm{C}$, but the molecular structure of the material will change.

At a temperature of about $190^{\circ} \mathrm{C}$, pyrolysis reactions begin to take place in the surface layers of the wood, the front of which moves into the material as it heats up (Fig. 1). This causes the decomposition of the least heatresistant components of wood, which is accompanied by the release of monoxides of carbon and nitrogen, chemically bound moisture and other products [18, 19]. The component composition of wood begins to change.

Biomass consists of three main polymer structures: cellulose, lignin and hemicellulose. Hemicellulose begins to decompose at a temperature of about $190{ }^{\circ} \mathrm{C}$, Its decomposition begins with the loss of moisture and the formation of volatile products. It is believed that the main destructive processes take place at a temperature of 220$280{ }^{\circ} \mathrm{C}$, with the maximum rate of weight loss corresponds to $240{ }^{\circ} \mathrm{C}$. [20].

Cellulose and lignin are more heat-resistant, so the decomposition of cellulose occurs in the temperature range $280-370^{\circ} \mathrm{C}$, the maximum speed of this process is at 335 ${ }^{\circ} \mathrm{C}$. Thermal decomposition of the main part of lignin occurs in the temperature range $200-540{ }^{\circ} \mathrm{C}$, with the maximum rate of weight loss is observed at $420{ }^{\circ} \mathrm{C}$ [20]

Thus, the decomposition of certain components will affect the overall weight loss, and in parallel will determine the degree of torrefaction. In order to identify the boundary points of this process, it is necessary to construct appropriate thermogravimetric curves, the analysis of which will allow us to talk about the optimality of processing in a particular mode.

To determine the parameters of weight loss at different processing temperatures, a number of studies were conducted for different types of raw materials. The results of measurements of relative weight loss are shown in Fig.2. And to bring them to the classical form of such studies, integral thermogravimetric curves are shown in Fig.3.

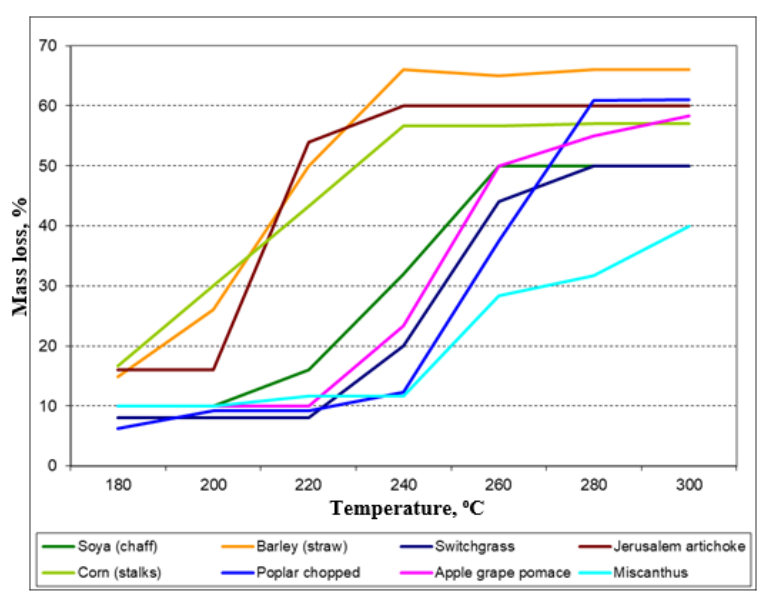

Fig. 2. Relative weight loss of some types of raw materials.

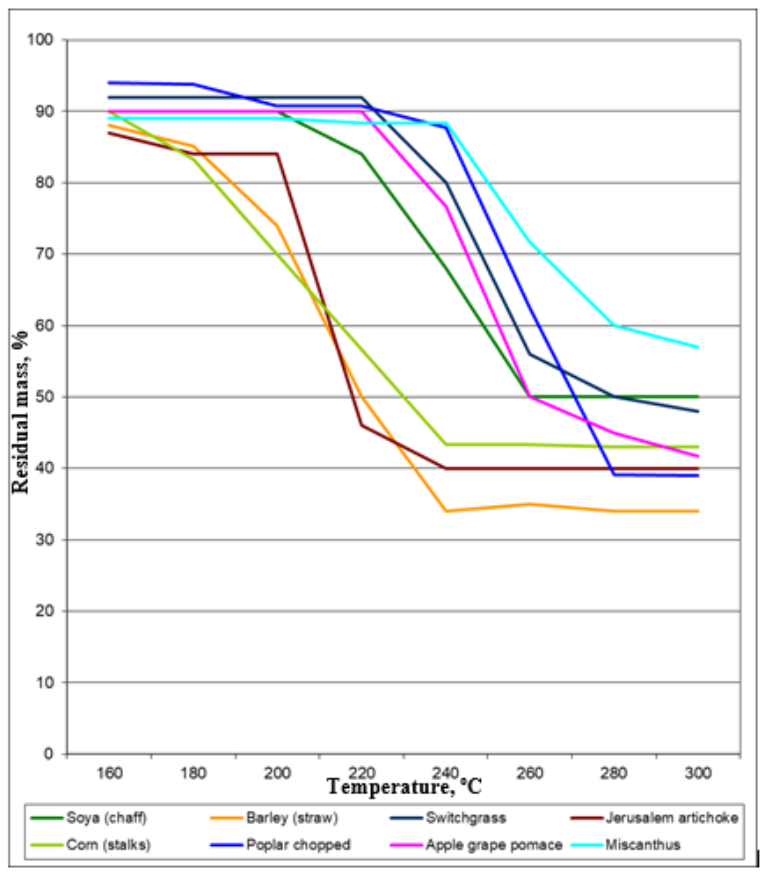

Fig. 3. Integral thermogravimetric curves of torrefaction of different types of biomass.

Analyzing the graphs, we see that the dynamics of changes in weight loss depending on the thermal treatment temperature for different biomass occurs on similar principles. At the initial stage, the curve is almost horizontal, or with a slight slope toward growth, depending on the initial humidity of the material. Obviously, as in the case of thermogravimetric curves (Fig. 2, 3) at this stage is the removal of free moisture and drying of the material. Further, there is a sharp increase in weight loss, which is apparently due to the internal destruction of organic matter of biomass and the removal of volatile substances. After some period of temperature, the curve stabilizes again, which indicates the end of the active phase of thermal transformations. This interval can be considered as temperature modes of torrefaction. As can be seen from the graphs, this interval has different values for different crops, but given that their definition does not require complex 
techniques and expensive equipment, this method can be a way of initial assessment of the parameters of torrefaction and the quality of torrefaction).

\section{CONCLUSIONS}

Thus, in the process of torrefaction, the potential energy of biomass is compacted by removing moisture from the wood, as well as volatile substances formed during the decomposition of hemicellulose and partial decomposition of cellulose and lignin. As shown by studies for most biomaterials of plant origin, we can distinguish the beginning of intensive transformation and its end, after which there is a sharp slowdown in weight loss, and, accordingly, and the energy density of the samples.

Thus, the control of weight loss and discoloration of biomass subjected to thermal treatment can be parameters of the initial assessment of the modes of torrefaction and the quality of torrefaction. And this in turn will allow without the presence of complex equipment in the production environment with sufficient accuracy to determine the necessary modes of torrefaction.

\section{REFERENCES}

[1] J. Arcate, "New process for torrefied wood manufacturing". Bioenergy update. vol. 2, 2000.

[2] A. Knapczyk, S. Francik and M. Jewiarz, "Robust optimization in production engineering-methods and application”. E3S Web of Conferences, 2019, pp.132. https://doi.org/10.1051/e3sconf/2019

[3] K. Mudryk, M. Wróbel and M. Jewiarz, "Innovative Production Technology of High Quality Pellets for Power Plants”. Renewable Energy Sources: Engineering, Technology, Innovation. Cham, Switzerland: $\quad$ Springer. 2018, pp. 701-712, https://doi.org/10.1007/978-3-319-72371-6_69

[4] B. Arias, C. Pevida and J. Fermoso, Eds., "Influence of torrefaction on the grindability and reactivity of woody biomass", Fuel Processing Technology, 89, 2008, pp. 169-175.

[5] T.G. Bridgeman, J.M. Jones and P-T. Williams, "Torrefaction of reed canary grass, wheat straw and willow to enhance solid fuel qualities and combustion properties”, Fuel 87, 2008, pp. 844-856.

[6] P.C.A. Bergman and J.H.A. Kiel, “Torrefaction for biomass upgrading”, Published at 14 th European Biomass Conference and Exhibition, Paris, France, ECNRX-05-180, 2005

[7] P.A. Mar'yandyshev, E.I. Popova, A.A. CHernov and V.K. Lyubov, "Izotermicheskoe issledovanie drevesnogo topliva i ego organicheskih koponentov" (Isothermal study of wood fuel and its organic components). Vestnik Cherepoveckogo gosudarstvennogo universiteta, № 2 (71), 2016, pp. 15-18.

[8] Z.B. Jankovich and M.M. Jankovich "Pyrolysis of pine and beech woodsamples under isothermal experimental conditions”. The determination of kinetic Cellulose Chemistry and Technology, 2013, Vol.47, pp. 681-697

[9] A. Knapczyk and S. Francik, "Analysis of research trends in the fieldof mechanical engineering”. Tehnologija. Resursi Environment, Technology, Resources, Vol. 2, 2019 , https://doi.org/10.17770/etr2019vol2.4170

[10] S. Yermakov, T. Hutsol and S. Slobodian, Eds., "Possibility of using automation tools for planting of the energy willow cuttings". Renewable Energy Sources: Engineering, Technology, Innovation. 2018. pp. 419-429.

[11] S. Yermakov, K. Mudryk and T. Hutsol, Eds., "The analysis of stochastic processes in unloadingthe energywillow cuttings from the hopper”. Environment. Technology. Resources. Rezekne, Latvia. Proceedings of the 12th International Scientific and Practical Conference. Vol. III. 2019. pp. 249-252, https://doi:10.17770/etr2019vol3.4159.

[12] M. Korchak, S. Yermakov and V. Maisus, Eds., "Problems of field contamination when growing energy corn as monoculture". E3S Web of Conferences. Krynica, Poland. 6th International Conference - Renewable Energy Sources. Vol.154, 2020.

[13] V. Ivanyshyn, S. Yermakov and T. Ishchenko, Eds., "Calculation algorithm for the dynamic coefficient of vibro-viscosity and other properties of energy willow cuttings movement in terms of their unloading from the tanker”. Proceedings of 6 th International Conference - Renewable Energy Sources, vol. 154, E3S Web of Conferences. 2020.2 pp. 04005, https://doi:10.1051/e3sconf/202015404005.

[14] S. Yermakov, T. Hutsol, O. Ovcharuk and I. Kolosiuk "Mathematic simulation of cutting unloading from the bunker". Independent journal of management \& amp; production (IJM\&P). Vol. 10, No. 7, 2019. pp. 758-777.

[15] T. Hutsol, S. Yermakov and Ju. Firman, Eds., "Analysis of technical solutions of planting machines, which can be used in planting energy willow”. Renewable Energy Sources: Engineering, Technology, Innovation. 2018. pp. 99-111.

[16] A. Tryhuba, T. Hutsol and S. Glowacki, Eds. "Forecasting Quantitative Risk Indicators of Investors in Projects of Biohydrogen Production from Agricultural Raw Materials”. Processes 2021, 9, pp/ 258. https://doi.org/10.3390/pr9020258

[17] A. Tryhuba, T. Hutsol and I. Tryhuba, Eds. "Risk Assessment of Investments in Projects of Production of Raw Materials for Bioethanol”. $\quad$ Processes. 2021; https://doi.org/10.3390/pr9010012

[18] V.M. Zajchenko, V.V. Kosov and V.A. Sinel'shchikov, "Torrefikaciya — sposob uluchsheniya potrebitel'skih harakteristik granulirovannogo topliva iz biomassy". (Torrefaction is a way to improve the consumer characteristics of pelleted biomass fuel.) Energotekhnologii i resursosberezhenie (Energy technologies and resource conservation). 2012. № 5. pp. 37-41.

[19] V.K. Lubov, E.I. Popova and K.S. Bolotova, Eds., “A study of wood torrefaction". Bulletin of the Cherepovets State University, 2017, no. 3 (78), pp. 38-45.

[20] P.A. Mar'yandyshev, A.A. Chernov and M.K. Eseev, Eds., "Issledovanie processa izotermicheskogo razlozheniya drevesiny”, Himiya tverdogo topliva. №6, 2016. pp. 51-59. 